Research on Tasmanian bones raises a number of ethical questions

SIR - Your News story about the repatriation of Tasmanian bones ("Aboriginal remains head for home" Nature 444, 411; 2006) largely ignores the ethics of scientific investigation of these remains. It is my understanding that the Natural History Museum in London is to gather data on these samples before returning them, which is a good compromise in the controversial circumstances. However, it is difficult to agree that - as some researchers seem to suggest - the remains should stay in the museum's possession indefinitely.

In modern science, for example in the field of medical research, we can proudly say that we strictly control the ethical aspects of our experiments, and do not carry out experiments on human samples obtained unethically or without permission. Not being a historian, I do not know the histories of the items in question. However, Tasmanian remains such as these were typically obtained without consent in circumstances that would now be considered unethical — including theft, grave-robbing and post-mortem mutilation (see Helen MacDonald Human Remains: Dissection and its Histories Yale Univ. Press, 2006).

These are not comparable to archaic remains found by archaeologists or palaeoanthropologists. Archaic remains are discovered in the course of science, not displaced at death and relocated to a site for investigation without permission from relatives. These Tasmanian remains are old, but they are not archaic.

Additionally, the scientific value of these remains is undear. The quoted phrase "Who knows what kind of questions we could ask?" does not provide a solid enough reason for investigating human remains. Scientists have to be specific in order to avoid criticism. If some researchers consider this a blow, they have to change their mindset and find alternative avenues of investigation. Most medical scientists wouldn't dream of carrying out experiments on human tissue that had been obtained unethically.

As for the issue of ownership, the burden of proof should be on the investigating scientists to show that their samples were obtained ethically, and that continuing investigation is warranted, rather than on descendants to prove ownership.

Is the suggestion that, if nobody can prove a genealogical link with the remains, then any course of investigation is warranted?

If only the Tasmanian Aborigines had been regarded with ethical consideration, they would not have been systematically exterminated. Science was not responsible for their deaths, of course, but we can derive lessons from this sad history. Perhaps sometimes we have to learn to put ethics and humanity above our scientific curiosity. Jason Coombes

Centre for Transplant and Renal Research, University of Sydney at Westmead Millennium Institute, Westmead, NSW 2145, Australia

\section{Increased funding vital to competitiveness initiative}

SIR - Your News story ${ }^{\alpha}$ Power shift stymies US science budget " (Nature 445, 130-131; 2007) states that staff at the US National Institute of Standards and Technology (NIST) are "apparently not too disappointed" by the prospect of Congress passing a continuing resolution that would limit funding to fiscal year (FY) 2006 levels rather than providing the increase of more than $24 \%$ in the agency's laboratory and facilities funding proposed by President Bush's FY 2007 budget. You quote a NIST spokesman as saying: ${ }^{\alpha}$ Proposed budgets rarely come through as proposed, so there were no emotions here."

This is not correct. NIST employees care deeply about their budget and these statements misrepresent the agency.

The initiatives proposed in the FY 2007 budget are essential to NIST's ability to fulfil its mission and are critical to the overall success of the president's American Competitiveness Initiative. A freeze in funding of NIST's core programme at 2006 levels would slow progress in a wide range of important areas, including safely exploiting nanotechnologies in a vast range of applications from paints to medicines to electronics; developing the measurement infrastructure required to support hydrogen fuels; and advancing basic physics to realize quantum computing.

There are a number of different ways in which Congress can implement a continuing resolution. Our hope would be that NIST will be allowed to move forward on as many of these critical priorities as possible.

William Jeffrey

National Institute of Standards and Technology, Gaithersburg Maryland 20899-1070, USA

\section{Five-point plan to revive and reform Indian science}

SIR - To arrest the dedine of Indian science, Prime Minister Manmohan Singh promises to double funding for science in the next five years, as you report on your News pages (Nature 445, 134-135; 2007). But there is still a need to make Indian science more attractive to talented young people, in terms of professional opportunities and financial incentives, free from academic feudalism.

Indian science has suffered a lot from an inward-looking crab mentality, a reluctance to share infrastructure, a disregard for scientific ethics, and the lack of a new generation of science leaders. Expensive instruments can be seen gathering dust in national institutes and universities, in the absence of coordinated planning. Mediocre bosses who grab credit from genuine researchers for their personal glorification are in no position to attract young talent to science. A system that rewards frivolous patents more than peer-reviewed publications has diluted its own quality.

Excessive pressure on scientists to generate income for their labs has forced researchers to deviate from their core competence to cater to the requirements of funding agencies. Self-financing courses have mushroomed, but they lack proper faculty and generate poorly educated graduates. This is good for statistics but bad for quality.

Singh's warning that increased funding requires better quality science may arouse those who are conscientious and capable, while causing panic among those who do not deserve their high profile. It could pave the way for a science renaissance.

For this to happen, however, certain immediate measures need to be taken. Universities' core infrastructure needs to be overhauled, with a primary focus on highquality education. Synergy and collaboration must be promoted between national institutes and centres of excellence in the universities, free from bureaucratic obstacles. Project leaders must have total freedom from unnecessary red tape, in order to attract contract research and competitive grants. Only accomplished, mature scientists must be put in the leadership role of science managers. And a statutory model code of scientific values and ethics must be created.

U.C. Lavania

Central Institute of Medicinal and Aromatic

Plants, Lucknow 226 015, India

\section{All sizes of needle in that overcrowded haystack}

SIR - The few lone top quarks that have been discovered are " 60 needles in a pretty large haystack" according to your News in Brief story ${ }^{\alpha}$ Fermilab team finds top quark going solo" (Nature 444, 983; 2006). Just a few pages further on, a Book Review tells us that the discovery of a body in the Kuiper Belt is "a classic case of finding a needle in a haystack" ( ${ }^{\alpha}$ The beginning of wisdom" Nature 444, $1006-1007 ; 2006$ ). That sure is a good few orders of magnitude for a metaphor.

Neville W. Goodman

Department of Anaesthesia,

Southmead Hospital, Bristol BS10 5NB, UK 